\title{
Break-up Strength of Flocs Analyzed Using Orifice Converging Flow
}

\author{
Yasuhisa ADACHI ${ }^{*}$, Motoyoshi KoBAYASHI*, and Yasuyuki FUKUHARA* \\ ${ }^{*}$ Graduate School of Life and Environmental Science, Tsukuba University \\ Tennoudai 1-1, Tsukuba-shi, Ibaraki 305-8572, Japan \\ ${ }^{* *}$ Faculty of Agriculture, Iwate University \\ Ueda 3-18-8, Morioka, Iwate 020-8550, Japan
}

\begin{abstract}
Break-up strength of flocs against hydrodynamic strain generated in a converging flow adjacent to orifice was analyzed using polystyrene latex flocs of different structures. A simple method to find the largest surviving floc after passing through the orifice as a function of flow rate allows us to evaluate the bond strength in flocs. It was confirmed that the strength of floc is constant irrespective of the diameter of floc as long as the number of contact between colliding clusters is constant. However, the strength increases with increasing number of contacts between clusters. This result is consistent with our previous result on the floc strength in a turbulent flow.
\end{abstract}

Key Words: Colloid / Floc / Break-up strength / Fractal structure / Converging flow

\section{オリフィス収縮流れを用いたフロックの破壊強度に関する研究}

\author{
足立 泰久*, 小林 幹佳 ${ }^{* *}$, 福原 康之* \\ (原稿受理：2006年8月21日）
}

\section{1. 緒言}

環境中に存在するコロイド粒子の表面には，さまざまな 污染物質が吸着濃縮されている。それらコロイド粒子の大 半は凝集体（フロック）として存在しており，その挙動を 知ることは污染物質の拡散を評価する上で重要である。コ ロイド分散系のレオロジーにおいても，系が凝集状態にあ るとき運動の単位はフロックであり, フロックの大きさ, 密 度，強度などの物理量が，系の流動や分離特性に関わる. ${ }^{1-4)}$ この内フロックの大きさは, 沈降速度などフロックの挙動 を支配する代表的な因子であるが，凝集したフロックが構 造を保とうとする方向に作用するフロック内のコロイド粒 子間の付着力（フロック強度）とフロックの破壊を促すフ ロックが流れ場から受ける流体力とのバランスで決まる. 小林ら 5 ,6) は, 乱流中のフロック破壊現象をShinnarが提出した 液滴破壊7の考え方に基づいて考察し，フロックの大きさが 乱れのマイクロスケールより小さいときは, 周囲の流れを単 純なせん断流れとして扱えること, せん断流れ場ではフロッ クの大きさの添加塩濃度依存性の大小関係がDLVO理論から 算定されるコロイド粒子間力と一致すること, ${ }^{8}$ ママイクロピ ペットを用いた破壊実験ではフロック強度はフロックの大 きさによらないこと, ${ }^{9)}$ の三つの実験事実を根拠に, フロッ ク強度 $F$ は，フロックが分裂するときに切断されるクラス

$*$ 筑波大学・大学院生命環境科学研究科 茨城県つくば市天王台 1-1-1

** 岩手大学農学部 岩手県盛岡市上田町 3-18-8
ター間の接点数 $N_{c}$ とひとつの接点の付着力 $f$ との積で決まる として,

$$
F_{\text {floc }}=f \times N_{c}
$$

と表した。この考え方の妥当性は，攪拌槽の乱流中に存在す るフロックの大きさを乱流強度の関数として解析すること によって検証された。しかし，乱流中において得られた実験 データの解析には統計的な操作を必要としており，フロック の破壊がどこでどのようにして生じているかを特定するこ とは容易ではない.

流体運動における速度変動の成分は伸張と回転に分けら れるが，回転は応力の生成に寄与しないので，フロックの破 壊に寄与寸るのは流れの伸張成分である，伸張流によるフ ロック破壊はオリフィス吸い込み口付近の収縮流を用いて 調べることができる. Sonntag と Russel ${ }^{10)}$ は，塩で凝集したフ ロックのオリフィス収縮流における破壊実験から，フロック の大きさを伸張速度の関数として求めた。 また，彼らはオリ フィス周囲の流れ場を差分法によって解き，オリフィス流心 部の伸張速度は周辺部に対し 10 分の 1 程度であること，伸張 速度はオリフィス流入直前で最大になること，などを示して いる。一方, Higashitani ら ${ }^{11,12)}$ は, オリフィスを通過するとき のフロックの破壊はフロックが周辺部から削り取られるよ うな侵食型の破壊ではなく，フロックの中央付近から大きな 塊に分かれる分裂型の破壊であること，オリフィスを通過す 
る際のフロックの大きさはオリフィス流入部の最大伸張速 度によって支配されていることを指摘した。 さらにBlaserは， オリフィス収縮流の流れ場に存在するフロックを棈円体で 近似し，楕円体表面の忘力を積分することによって楕円体に 作用する流体力を求めた. ${ }^{13,14)}$ Blaserは, この結果を破断面を 想定して単位面積当たりの力として整理しているものの, ${ }^{15)}$ フロックを構成する粒子間の付着力に結び付けるところま で解析を進めていない.

以上の結果を踏まえ, 小林は16), まず, オリフィス通過後 に残存するフロックのうち最も大きなフロックは, オリフィ スを通過する際に流体から受ける破断力が最も小さくなる オリフィス流心部を通過したものであるとし，この仮定に基 づいてオリフィス通過後のフロックの粒径分布から径が最 大となるものを選んで, オリフィス流心部の伸張速度を適用 して, フロックの強度を算定する方法を提案した. 次に, そ の方法に基づいてフロック破壊の実験を行い, オリフィス収 縮流において破壊に耐えうるフロック強度は, フロックの大 きさによらずほぼ一定であることを示した。この結果は(1)式 における $N$ が一定であれば，Fが一定となることと等価であ るが，(1)式の妥当性を示す観点からは， $N_{c}$ を変化させたフ ロックを用いて確認の実験を行う必要がある. そこで本研究 では, 希薄な分散系を用いて急速凝集条件下で静置した容器 内でブラウン運動のみによって凝集させたフロック（広い粒

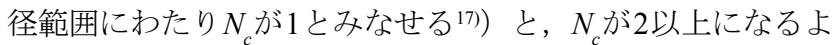
うに濃厚な分散系を用いて転倒攪挥 ${ }^{18,19)}$ によって作成したフ ロックの2種類のフロックを用いてオリフィス収縮流を用い たフロックの破壊実験を行い，小林の提案した方法および(1) 式の有効性を検証する.

\section{2. オリフィス収縮流を用いたフロック強度の 測定原理}

フロックの破壊はその表面に作用する流体力 $F_{h y d}$ がフロッ ク強度を上まわったとき，すなわち，

$$
F_{h y d} \geq F_{f l o c}
$$

となったときに生じる. オリフィスを通過するフロックはオ リフィス直前の収縮流部で最大の応力を受ける. そのため, ここでの破壊がオリフィス下流に流出するフロックの大き さを決定する. 収縮流部では, フロックはその表面に受ける 忘力により引き伸ばされ楕円体に近い形状になる. Blaserは 引き伸ばされ楕円体に近い形状になったフロックを剛体の 偏長楕円体として近似し，作用する流体力を，

$$
F_{h y d}=\frac{C_{h y d} \mu \gamma S}{2}
$$

と求めた. ここで $C_{h y d}$ は流れ場によって変形したフロックを 楕円体として近似した場合に長軸 $\left(=d_{\text {maj }}\right)$ と短軸 $\left(=d_{\text {min }}\right)$ の 比により決定される形状係数であり, Blaserの計算結果 ${ }^{14)}$ から 小林 ${ }^{16)}$ により Table I に示した值が得られている. また， $\mu$ は 粘性係数, $\gamma$ はフロックが存在する流れ場の伸張速度であり, オリフィス中心軸上では, 最大值がオリフィスの入り口直前 で生じ,

$$
\gamma=\frac{3 \sqrt{3} Q}{32 \pi R^{3}}
$$

と求められている.ここで, $Q$ は体積流量, $R$ はオリフィスの 半径である。また，Sは楕円体の表面積であり，

$$
S=\frac{\pi}{2}\left(\frac{d_{m a j}^{2} d_{m i n}}{\sqrt{d_{m a j}{ }^{2}-d_{m i n}^{2}}} \arccos \frac{d_{m i n}}{d_{m a j}}+{d_{m i n}^{2}}^{2}\right)
$$

で与えられる，したがって，オリフィス通過後に残存する最 大のフロックが，オリフィスの中央部を通過してきたものと 仮定することにより, 各流量 $Q$ に対し, 最も大きなフロック を選んで画像解析によって， $d_{m i n}, d_{m a j}$ を決定し，(3)-(5)を適用 すれば,

$$
F_{\text {hyd }}=F_{\text {floc }}
$$

とおいて, フロック強度 $F_{f l o c}$ を求めることができる.

\section{3. 実験}

\section{1 実験材料}

本研究ではコロイド粒子として直径 $2.8 \mu \mathrm{m}$ のポリスチレン ラテックス (以下PSL) 粒子 (Interfacial Dynamics 社より購入) を用いてフロックを形成し実験に供した。この粒子の密度は $1.055 \mathrm{~g} / \mathrm{cm}^{3}$ であり, $1.24 \mathrm{M}$ の塩化カリウム $(\mathrm{KCl})$ 水溶液中に おいて，重力の影響を無視小として，急速凝集の条件でフ ロックを形成することができる.

オリフィス破壊の実験に際しては，フロック形成時のクラ スター間接点数 $N_{c}$ を制御する観点から, 初期粒子数濃度 $4.9 \times 10^{7} \mathrm{~cm}^{-3}$ にて 5 日間静置してブラウン凝集によって形成し たフロック（以下 $\mathrm{B}-フ ロ ッ ク ）\left(N_{c}=1\right.$ を仮定）と，初期粒子 数濃度を $3.2 \times 10^{8} \mathrm{~cm}^{-3}$ に設定して 2 時間転倒攪拌 ${ }^{18,19)}$ によって 乱流状態で形成したフロック（以下 $\mathrm{T}-フ ロ ッ ク ） （ N_{c}>1$ を仮 定）の2種類のフロックを用意した. ${ }^{17)} \mathrm{B}$-フロック， T-フロッ クの顕微鏡画像をFig. 1に示寸. 図に示されているとおり, Bフロックは枝状に発達したよりかさばった構造をしており, またそれに比してT-フロックは角が丸くなり粒子同士が内部 に密に充填された構造をとっている.

\section{2 フロック破壊の実験装置と手順}

フロック破壊の実験は(3)式を用いてフロック強度 $F_{f l o c}$ を算 出するためにそのパラメーターである $\gamma, C_{h y d}, S$ を決定する ために行った。 $\gamma$ は(4)式により決定される. 実験装置の構成 をFig. 2に示す．実験手順は以下のとおりである.

Table. I Shape factor of ellipsoid ( $\left.C_{h y d}\right)$ used in Eq. (3).

\begin{tabular}{|l|l|}
\hline $\mathrm{d}_{\text {maj }} / \mathrm{d}_{\min }$ & $C_{\text {hyd }}$ \\
\hline $1.0-1.6$ & 5.00 \\
\hline $1.6-2.8$ & 5.25 \\
\hline $2.8-3.6$ & 5.50 \\
\hline $3.6-4.2$ & 5.75 \\
\hline
\end{tabular}


1. 作成したフロックをPSL粒子と等しい密度に濃度を調整し た KCl溶液を満たしたガラスカラムの中に入れる. ガラス カラムの下端にはシリコン栓がはめ込まれ, その中央部に

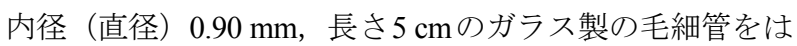
め込みオリフィス部を構成した. カラムへのフロックの移 行作業は内径 (直径) が $10 \mathrm{~mm}$ のガラス管を用いてフロッ クに過剩なストレスがかからないよう慎重に行った.

2. この毛細管とシリンジをシリコンチューブにより接続し, モーターによりシリンジのピストンを引くことでオリ フィス収縮流を発生させた.

3. シリンジをつなぐチューブ内に存在している破壊され たフロックを毛細管と毛細管に接続されている側のシ リコンチューブをはずし, スライドガラスにO-リングを取 り付けた容器にゆっくりと移す。この際, 毛細管からはず した方のチューブの先端に存在する溶液はコンタミネー ションを避けるために捨てる.これを顕微鏡のステージに 移し観察を開始する.

4. O-リングに移した溶液中に存在するフロックを全て観察し, 最も大きい物から 10 サンプルを顕微鏡に接続したCCDカ メラにより撮影した.
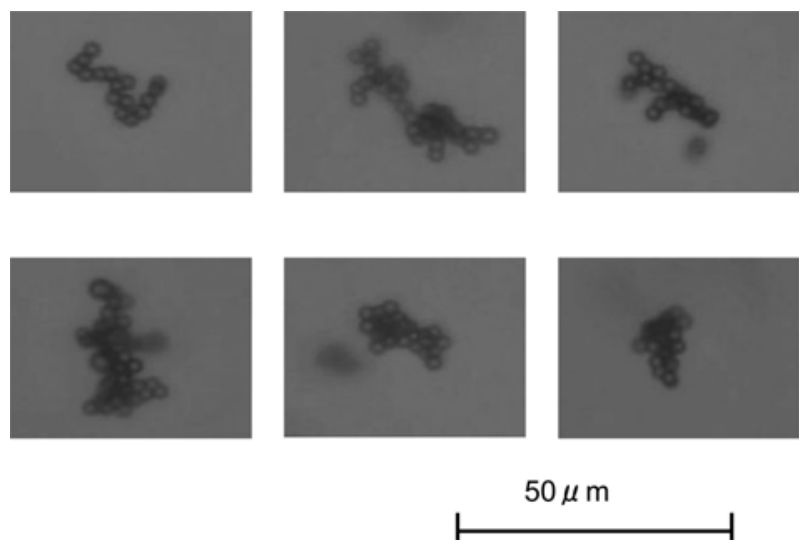

Fig. 1. Snap shots of B-flocs(upper berth) and T-flocs(lower berth) used in break-up experiment through orifice.

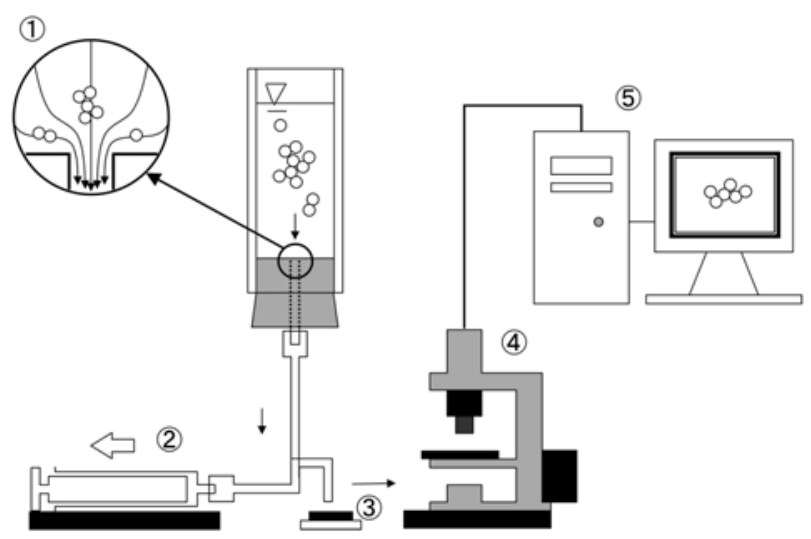

Fig. 2. Schematic illustration of experimental setup. (1) Orifice. (2)Syringe pump. (3) Slide glass + O-ring. (4) Microscope + CCD camera. (5).C.(Scion image).
5. 以上の工程を一つのサンプルにつき流量を6段階に変化さ せ，各流量につき3回ずつ計18回の測定を行った.

6. 5 で撮影したフロックの画像をScion corporationより配布さ れているScion imageを用いて，楕円体として近似し，そこ から長軸 $\left(d_{m a j}\right)$ と短軸 $\left(d_{\text {min }}\right)$ を決定した. なお, 画素の

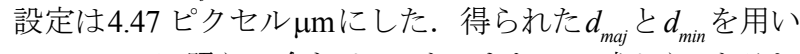
て，Table Iに照らし合わせ $C_{h y d}$ を，また，(4)式から $S$ をそれ ぞれ決定した. (3)式の $Q$ にはピストンの移動速度から求め た流量を用い，Rは $0.45 \mathrm{~mm}$ とした。これにより $\gamma$ を決定し た. 以上の值を(3)式に代入することで $F_{f l o c}$ を得た.

\section{4. 結果と考察}

B-フロックをオリフィス収縮流を用いて破壊したときの 流量 $Q$ と通過後のフロックの長軸径 $d_{m a j}$ の関係をFig. 3 に示す. この結果から $Q$ が増加するにつれて,$d_{m a j}$ が減少していること が確認される. 同様の操作を $\mathrm{T}$-フロックについて行った結果 がFig. 4である. 同様に，Qが増加するにつれて， $d_{m a j}$ が減少 していることが確認される. 次にFigs. 3-4に示されたデータ を用い(3)-(6)式に基づいて, フロック強度 $F_{f l o c}$ を求めた. Fig. 5 は，得られた值を $d_{m a j}$ の関数として示したものである. 図に 示されたように, B-フロックでは $F_{f l o c}$ は $d_{m a j}$ によらずほぼ一定 の值 $\left(1.0 \times 10^{-9} \mathrm{~N}\right)$ をとっている，すなわち， $N_{c}=1$ が仮定でき るようなB-フロックについては, フロック強度は大きさによ らずほぼ一定の值となることが確認された. Hodges ら ${ }^{20)}$ は AFMを用いた測定によって, 水中での高分子ラテックス間の 付着力の直接測定を試み，向かい合った面に対し鉛直方向に

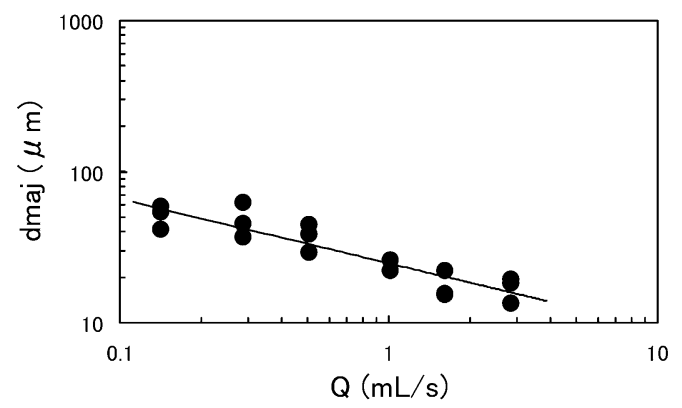

Fig. 3. Maximum floc diameters $\left(d_{m a j}\right)$ against flow rate in the orifice for B-flocs.

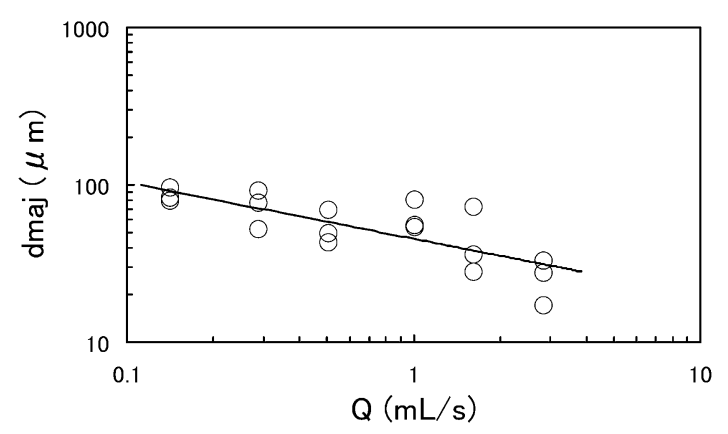

Fig. 4. Maximum floc diameters $\left(d_{m a j}\right)$ against flow rate in the orifice for T-flocs. 
引き剥がした場合, 得られた付着力は1 数 $\mathrm{nN}$ であること, ま たデータのバラツキはラテックス表面の粗さ (roughness) に よるものとしている. 今回我々が求めた数值はHodgesらの測 定結果の下限值に近く，そのバラツキは小さい。流れ場にお いてフロックが破壊される場合には，フロック内部の粒子間 付着力の弱い部分が選択的に切断されているとすれば, 我々 の求めたフロック強度はHodgesらの測定值に対しても整合性 のある解釈ができる. 尚, B-フロックに対し求められたフ ロック強度の数值 $1.0 \times 10^{-9} \mathrm{~N}$, 半径 $r_{0}$ の球状粒子間の付着力 をファンデルワールスカのデリアギン近似から算出する公 式21)

$$
F=-\frac{A r_{0}}{12 h^{2}}
$$

に照らし合わせ，八マカー定数として $A=1 \times 10^{-21} \mathrm{~J}^{22)}$ を代入す れば，フロックを形成するコロイド粒子の表面間距離として $h=0.3 \mathrm{~nm}$ が得られる.

一方， T-フロックについて求めたフロック強度は, B-フ ロック值に対し数倍程度の大きさを示し，また，わずかなが らフロック径の増大に伴い増加する傾向を示しており，さら にその数值のばらつきが大きいことが示された. (1)に照らし 合わせれば，転倒攪找によって形成される T-フロックではク ラスター間接点数が 2 以上に増加して成長したことを反映し ており，フロックが成長するとクラスター間接点数のばらつ きが大きくなることを反映しているためと解釈することが できる.

\section{5. 結 論}

オリフィス直前の収縮流によってフロックを破壊し, その 破壊強度をひずみ速度の関数として解析した. 実験には, 球 状ポリスチレンラテックス粒子の分散系に十分高い濃度の $\mathrm{KCl}$ 溶液を加え, 急速凝集条件下にて形成させたフロックを 適用した. 乱流中のフロックの破壊強度に対し, 筆者らが提 出した, フロック強度はフロックを構成するクラスター間の 接点数と接点一つあたりの付着力の積によって決定される とした考え方の有効性を検討するために, ブラウン運動およ び転倒攪拌によって生じる乱流を用いてコロイド粒子を凝 集させることによって, 異なる構造を有するフロックを意図

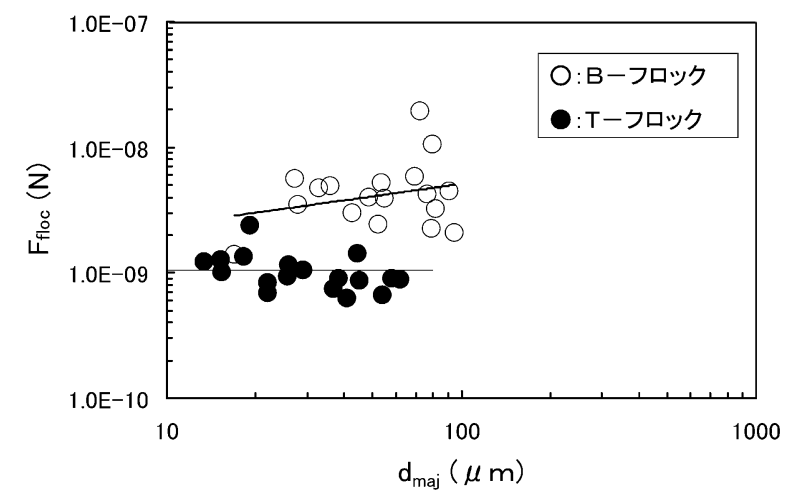

Fig. 5. Strength of floc against floc size.
的に形成し，実験に供した。ブラウン凝集によるフロックに 対しては, 求められたフロック強度はフロックの大きさによ らずほぼ一定の值となった. また, クラスター間接点数 $N_{c}=1$ を仮定して得たフロック強度の数值はファンデルワールス 力から算出される粒子間の付着力の数值に対し妥当な值と なった。一方，密に充填された乱流条件下で形成したフロッ クは，ブラウン運動によって形成したフロックに対し数倍程 度の強度となり，その值のバラツキが大きくなった。一連の 実験から，フロック強度の解析にオリフィス収縮流の適用が 有効であること，フロック強度の評価にはクラスター間接点 数の特定が重要であることが確認された.

\section{謝辞}

本研究は科学研究費補助金（No.16208023，18688013）によ り実施された.

\section{REFERENCES}

1) Tambo N, Watanabe Y, Suido Kyokai Zasshi, 397, 2 (1964).

2) Chen D, Doi M, J Chem Phys, 91, 2656 (1989).

3) Larson R G, "The Structure and Rheology of Complex Fluids", (1999), Oxford University Press, New York.

4) Miyahara K, Ooi S, Nakaishi K, Kobayashi M, Adachi Y, Nihon Reoroji Gakkaishi, 32, 277 (2004).

5) Kobayashi M, Adachi Y, Ooi S, Langmuir, 15, 4351 (1999).

6) Kobayashi M, Adachi Y, Ooi S, J Hydroscience and Hydraulic Engineering, 20, 179 (2002).

7) Shinnar R, J Fluid Mech, 10, 259 (1960).

8) Sonntag R C, Russel W B, J Colloid Interface Sci, 113, 399 (1986).

9) Yeung A K C, Pelton R, J Colloid Interface Sci, 184, 579 (1996).

10) Sonntag R C, Russel W B, J Colloid Interface Sci, 115, 390 (1987).

11) Higashitani K, Inada $\mathrm{N}$, Ochi $\mathrm{T}$, Colloids and Surfaces, 56 (1991).

12) Higashitani $\mathrm{K}$, Tnise N, Yoshiba A, Kondo A, Murata H, $J$ Chem Eng Jpn, 25 (1992).

13) Blaser S, Colloids and Surfaces A, 166, 215 (2000).

14) Blaser S, Chem Eng Sci, 57, 515 (2002).

15) Blaser S, J Colloid Interface Sci, 225, 273 (2000).

16) Kobayashi M, Colloids and Surfaces A, 235, 73 (2004).

17) Adachi Y, Kobayashi, Yanagibashi T, Trans JSIDRE, 233, 49 (2004).

18) Adachi Y, Cohen Stuart MA, Fokkink R, J Colloid Interface Sci, 165, 310 (1994).

19) Aoki K, Adachi Y, J Colloid Interface Sci, 300, 69 (2006).

20) Hodges C S, Cleaver J A S, Ghadiri M, Jones G, Pollock H, Langmuir, 18, 5714 (2002).

21) Israelahchvili J, "Intermolecular and Surface Forces", 2nd ed., (1992), Academic Press, London.

22) Adachi Y, Adv Colloid Interface Sci, 56, 1 (1995). 